\title{
FISH WASTE AND SHRIMP HEAD SILAGE AS DIETARY ROTEIN SOURCES FOR NILE TILAPIA, Oreochromis niloticus
}

\author{
T.M. Srour
}

Department of Animal and Fish Production, Faculty of Agriculture (Saba Basha), Alexandria University

\section{SUMMARY}

This study was conducted in nylon net enclosures system with two replicates for each combination to assess the effect of replacing fish meal protein (FMP) with 0 , 15, 30, 45 and $60 \%$ of fish waste silage protein (FWSP) or shrimp head silage protein (SHSP) in diets for Nile tilapia (Oreochromis niloticus). The experimental diets were isonitrogenous (crude protein $32 \%$ ) and isocaloric (423.70 kcal gross energy $/ 100 \mathrm{~g}$ of dry matter). Diets were fed to fingerlings of Nile tilapia (mean weight $12.4 \mathrm{~g} \pm 0.3$ ) at $3 \%$ of body weight per day (6 days a week) for 14 weeks. The results indicated that the replacement levels of FMP by FWSP had nonsignificant effects $(P>0.05)$ on growth performance and feed conversion ratio when compared with the control group. On the other hand, as FWSP or SHSP levels increased, PPV (\%) decreased with nonnsignificant difference between that receiving $15 \%$ FWSP and the control group. The higher percentage of energy utilization (EU) was achieved by fish fed on the control diet and that fed on diet containing $30 \%$ SHSP with significant $(P<0.05)$ differences from the other groups. Carcass compositions differed marginally in the fish fed the different diets. The results of the economic evaluation manifested that the feed cost and the changes in the cost $/ \mathrm{kg}$ fish gain were decreased with increasing replacement of FMP by FWSP or SHSP. It could be suggested that fish waste and shrimp head silage are promising alternative protein sources for Nile tilapia to replace FMP with 60 and $30 \%$, respectively without adverse effects on fish growth.

Keywords: Nile tilapia, fish waste silage protein, shrimp head silage protein, Growth, Feed utilization, Body composition, Economic evaluation

\section{INTRODUCTION}

The development of aquaculture is hampered by inadequate supply of feedstuffs particularly fish meal which is scarce and expensive (Nwanna, 2003). Fish meal is the preferred dietary animal protein source for many farmed fish and shrimp species, and is valued for its amino acid balance, vitamin content, palatability and unidentified growth factors (Tacon, 1993). Vegetable protein sources are often deficient in some essential amino acids. However, the composition of these ingredients may be improved by adding protein rich products such as fishmeal, silages, or hydrolysates. Alternative animal sources, such as squid meal, shrimp/prawn meal (Mohammed, 1977), meat and bone meal, hydrolyzed feather meal, flashings meal and blood meal (Paul et al., 1997 and Hu, et al., 2008), dried fish and chicken viscera (Srour, 2005 and Giri et al., 2000) have been used to replace part or all the fish meal in fish diets. Even these pooled meals of various animal protein sources were not sufficient to meet the growing demands of fish raising industry.

Issued by The Egyptian Society of Animal Production 
On the other hand, about $50 \%$ of the world fish production becomes waste material, which means an expressive amount of 65.2 million metric tons of fish waste (Ferraz de Arruda, 2004). Addition to the daily un-sold fish in markets and the wasted during capture, commercialization, stunted tilapia populations often result from overpopulation caused by frequent and prolific breeding in enclosed systems, these are regarded as low-value and undesirable for human consumption. However, they have potential as a feedstuff (Foltz et al., 1982) and are ideally suited for fishsilage preparation. Similarly, shrimp heads comprise $>33 \%$ of the whole raw shrimp production and are discarded as waste (Balogun and Akegbejo-Samsons, 1992). At the same manner, one of such alternatives is fish silage prepared from whole fish, fishery wastes by-products or fish farm mortalities (Lo et al., 1993). Fish silage is prepared either by mineral and/or organic acid preservation (acid silage) or by anaerobic microbial fermentation (fermented silage), (Fagbenro et al., 1994). Ensilation represents a simple, practical and economic process of trash fish and shrimp utilization for the manufacture of animal feeds and crop fertilizers (Ockerman, 1992; Gao et al., 1992 and Lo et al., 1993). During silage processing, enzymes found in muscles hydrolyze proteins and nitrogen becomes more soluble. Proteins are hydrolyzed to free amino acids, thus making silage the most available amino acid source for protein biosynthesis (Espe et al., 1989).

The advantages in the production of silage, compared to fish meal, are: the process is virtually independent from the scale; the technology is simple; the investment is little, even in large-scale production; reduced effluents and odor problems. It can be produced from undesirable fish farm, shrimp heads, dead fish, sub-utilized species, by-products from marine fishing, commercial fish waste and industrial residues. These if not used may cause environmental, health, and economic problems. Fish silage contains high levels of protein with excellent amino acid profile compared to the fish meal (Meyers, 1986). However, a disadvantage is that the silage is voluminous if consumed in its pasty form, implying an additional drying cost (Kompiang, 1981 and Beerli et al., 2004).

Therefore, this paper dealt with the utilization of fish waste and shrimp head silage as fish feed ingredients and the effects of their feeding on growth performance, feed utilization and carcass composition of Nile tilapia fish.

\section{MATERIALS AND METHODS}

The present study was undertaken in a private farm called Halk El-Gamal (ElBehera Governorate, Egypt) to study the impact of incorporating fish waste and shrimp head silage protein into Nile tilapia diet on growth performance, feed utilization and carcass composition.

\section{Fish and Culture Facilities}

Nile tilapia (O. niloticus) of mean weight $12.4 \pm 0.3 \mathrm{~g}$ were obtained from the same mentioned farm. An earthen pond of one feddan $\left(4200 \mathrm{~m}^{2}\right), 1$ meter in depth ( $80 \mathrm{~cm}$ depth of water allowance) containing 18 nylon net enclosures $(100 \mathrm{H} \times 80 \mathrm{~W}$ $80 \mathrm{~L} \times \mathrm{cm}$ in diameter) were used in the experiment. About $50 \%$ of the earthen pond water was changed every week. Fish were randomly distributed into the net enclosures (10 fish per unit) .Each treatment was performed in two replications. 


\section{Experimental Diets}

\section{Fish waste and shrimp head silage preparation}

Undesired small tilapia, unmarketable marine fish, fishery fish by-products and shrimp heads were collected from farms, markets, Abo Keer fishing region and restaurants, respectively. These residues were thoroughly rinsed in fresh water before blended into paste in separately two groups (fish waste and shrimp heads) using an industrial meat-grinding with approximately $3 \mathrm{~mm}$ in diameter. To obtain fermented silage, the following mixture was added to the paste in a wet weight basis: $15 \%$ sugar cane molasses, $5 \%$ Lactobacillus plantarum culture material and $0.3 \%$ propionic acid as a fungicide. The mixture was allowed to ferment for 14 days in black air tight plastic bags. The $\mathrm{pH}$ of the silage dropped from the initial value of 7 to 4 on the $14^{\text {th }}$ day. The liquid product was then co-dried with soybean meal (filler) and oven dried at $60^{\circ} \mathrm{C}$ for $48 \mathrm{~h}$ (Goddard and Al-Yahyai, 2001). The dried product was ground into fine powder to form the fish waste and shrimp heads silage meal and stored at $-20^{\circ} \mathrm{C}$ prior to further processing. The other diets ingredients were bought from the local markets.

Table 1. Chemical composition of fish waste silage (FWS) and shrimp head silage (SHS) as percentage of dry matter

\begin{tabular}{|c|c|c|c|c|c|c|c|}
\hline \multirow{2}{*}{ Ingredients } & \multirow{2}{*}{$\mathrm{DM}$} & \multicolumn{5}{|c|}{ Composition (\%), DM basis } & \multirow{2}{*}{$\begin{array}{c}\text { Gross } \\
\text { energy* }\end{array}$} \\
\hline & & $\mathrm{CP}$ & $\mathrm{EE}$ & Ash & $\mathrm{CF} /$ Chitin & $\mathrm{NFE}$ & \\
\hline Fish meal & 89.5 & 59.3 & 10.6 & 29.0 & 1.1 & - & 434.516 \\
\hline FWS & 87.4 & 51.7 & 7.9 & 15.5 & 7.8 & 17.1 & 424.548 \\
\hline SHS & 88.6 & 46.3 & 9.3 & 16.8 & 9.2 & 18.4 & 436.445 \\
\hline
\end{tabular}

Afterward, both of fish waste silage (FWS) and shrimp head silage (SHS) were incorporated separately into the diets, where, FWS or SHS protein replaced FM protein at a level of $0,15,30,45$ and $60 \%$ (Table 2). All diets were sufficient in essential vitamins and trace minerals (NRC, 1993). Diet ingredients were thoroughly mixed in plastic containers. Oil was added, a few drops at a time, during mixing. Warm water $\left(45^{\circ} \mathrm{C}\right)$ was slowly added under continuous mixing until the diets began to clump. The diets were passed through commercial meat mincer three times, and dried for $24 \mathrm{hrs}$ at $70^{\circ} \mathrm{C}$ in a drying oven. Dried diets were stored in a freezer at $-20^{\circ}$ $\mathrm{C}$ throughout all experimental period. All diets were formulated to be isonitrogenous (32\% protein, according to NRC, 1993) and isocaloric. The diets were fed to the experimental fish two times a day (10:00 and 15:00 hr) at a rate of $3 \%$ of live body weight on feed dry weight basis for 14 weeks ( 6 days a week). The fish were weighed every 2 weeks and the amount of diet fed was adjusted accordingly.

Chemical compositions of fish meal (FM), fish waste silage (FWS) and shrimp percentages of dry matter $(\mathrm{DM})$, crude protein $(\mathrm{CP})$, ether extract $(\mathrm{EE})$ and ash are shown in Table 1. Fish meal contained high percentage of CP, EE and ash with low crude fiber. No nitrogen free extract (NFE) was detected. NFE in FWS and SHS was increased due to the amount of molasses added during the preparation of the silage. 
Table 2. Ingredients (\%) and chemical composition of the experimental diets

\begin{tabular}{|c|c|c|c|c|c|c|c|c|c|}
\hline \multirow{2}{*}{ Items } & \multirow{2}{*}{ Control } & \multicolumn{2}{|c|}{$15 \%$} & \multicolumn{2}{|c|}{$30 \%$} & \multicolumn{2}{|c|}{$45 \%$} & \multicolumn{2}{|c|}{$60 \%$} \\
\hline & & FWS & $\overline{\text { SHS }}$ & FWS & $\overline{\text { SHS }}$ & FWS & $\overline{\text { SHS }}$ & $\overline{\text { FWS }}$ & $\overline{\text { SHS }}$ \\
\hline Fish meal & 24.00 & 20.40 & 20.40 & 16.80 & 16.80 & 13.20 & 13.20 & 9.60 & 9.60 \\
\hline FWS & - & 4.13 & - & 8.26 & - & 12.39 & - & 16.52 & - \\
\hline SHS & - & - & 4.60 & - & 9.20 & - & 13.80 & - & 18.40 \\
\hline Soybean & 36.70 & 36.70 & 36.70 & 36.70 & 36.70 & 36.70 & 36.70 & 36.70 & 36.70 \\
\hline Corn & 2 & 00 & 22.00 & 22.00 & 22.00 & 22.00 & 22.00 & 22.00 & 22.00 \\
\hline Bro & & 47 & 5.00 & 4.94 & 4.00 & 4.41 & 3.00 & 8 & 2.00 \\
\hline Whe & & 30 & 7.30 & 7.30 & 7.30 & 7.30 & 7.30 & .30 & 7.30 \\
\hline Vege & 2.00 & 2.00 & 2.00 & 2.00 & 2.00 & 2.00 & 2.00 & 2.00 & 2.00 \\
\hline Vit. \& Mir & 2.00 & 2.00 & 2.00 & 2.00 & 2.00 & 2.00 & 2.00 & 2.00 & 2.00 \\
\hline Total & 100 & 100 & 100 & 00 & 100 & 100 & 100 & 100 & 100 \\
\hline \multicolumn{10}{|c|}{ Proximate composition (\%) } \\
\hline Dry matter & 89.20 & 88.40 & 88.70 & 88.60 & 88.70 & 88.50 & 88.70 & 88.20 & 88.40 \\
\hline \multicolumn{10}{|l|}{ On dry matter } \\
\hline Crude pr & 32.06 & 32.10 & 32.00 & 32.11 & 32.01 & 31.98 & 32.14 & 32.08 & 31.99 \\
\hline Eth & & 7.01 & 7.12 & 6.96 & 7.15 & 6.90 & 7.19 & 6.84 & 7.23 \\
\hline NFE & 42.82 & 42.97 & 42.74 & 43.15 & 42.6 & 43.47 & 42.34 & 43.55 & 42.50 \\
\hline $\mathrm{Cr}$ & & 4.99 & 5.09 & 5.27 & 5.47 & 5.55 & 5.84 & 5.83 & 6.22 \\
\hline Ash & 13.33 & 12.93 & 13.05 & 12.51 & 12.77 & 12.10 & 12.49 & 11.70 & 12.06 \\
\hline Tota & 100 & 100 & 100 & 100 & 100 & 100 & 100 & 100 & 100 \\
\hline $\mathrm{GE}^{3}$ & 423.64 & 423.83 & 423.35 & 424.15 & 423.12 & 424.17 & 423.16 & 424.49 & 423.35 \\
\hline $\mathrm{P} / \mathrm{E}$ ratio $^{4}$ & 75.68 & 75.74 & 75.59 & 75.71 & 75.65 & 75.40 & 75.95 & 75.57 & 75.56 \\
\hline \multicolumn{10}{|c|}{$\begin{array}{l}{ }^{1} \text { Meveco premix, Vit. \& Min., every } 1.5 \mathrm{~kg} \text { contains Vit. A } 5 \text { million IU, } \mathrm{D}_{3} 3 \text { million IU, E } 15 \mathrm{~g}, \mathrm{~K}_{3} 2.5 \mathrm{~g}, \mathrm{~B}_{1} \\
1.5 \mathrm{~g}, \mathrm{~B}_{2} 5 \mathrm{~g}, \mathrm{~B}_{6} 2 \mathrm{~g} \text {, Pantothanic acid } 10 \mathrm{~g}, \mathrm{~B}_{12} 0.01 \mathrm{~g} \text {, Nicotenic acid } 30 \mathrm{~g} \text {, , Folic acid } 1.2 \mathrm{~g}, \mathrm{Fe} 30 \mathrm{~g}, \mathrm{Mn} \\
60 \mathrm{~g}, \mathrm{Cu} 10 \mathrm{~g}, \mathrm{I} 1 \mathrm{~g} \text {, Cobalt } 0.25 \mathrm{~g} \text {, Se } 10 \mathrm{~g} \text { and } \mathrm{Zn} 55 \mathrm{~g} \text {. } \\
{ }^{2} \text { Nitrogen free extract calculated by difference. } \\
{ }^{3} \text { Gross energy (Kcal/100g DM), calculated on the basis of } 5.64,4.11 \text { and } 9.44 \mathrm{Kcal} \mathrm{GE} / \mathrm{g} \text { protein, NFE and } \\
\text { lipid, respectively (NRC, 1993). } \\
{ }^{4} \text { Protein to energy ratio (mg/Kcal) }\end{array}$} \\
\hline
\end{tabular}

Data presented in Table 2, exhibit the composition and the chemical analysis of the diets used in the experiment. All diets were roughly isocaloric and isonitrogenous (32.05 \% and $423.70 \mathrm{kcal}$ gross energy/100 $\mathrm{g}$ of dry matter, respectively). Accordingly, the average of protein to energy ratio was $75.65 \mathrm{mg} / \mathrm{kcal}$ in average. Notably, CF (\%) increased with increasing fish waste silage proteins (FWSP) and shrimp head silage protein (SHSP).

\section{Sample Collection and Analysis}

Identical and random samples of FWS and SHS were taken and kept for proximate chemical analysis before diets preparation. At the termination of the experiment, fish were collected, weighed and counted per each replicate in each treatment. Four fish were randomly selected from each of the experimental net enclosure per treatments and weighed individually. They were, then, dissected, the livers removed and weighed individually too. Hepatosomatic Index was calculated as: HSI $=100$ (wet weight of liver/wet weight of fish). However, another sample from each experimental unit was oven dried at $60-80^{\circ} \mathrm{C}$ for $48 \mathrm{hrs}$, and then ground to minute particles. Finally, fish samples and the experimental diets were chemically analyzed following the AOAC (1999) standard procedures. The nutrition equations used were according to Hepher (1988). All data were statistically analyzed with 
ANOVA, and examined by linear regression modeling using SAS package for the IBM-PC (SAS User's Guide, 1988). Duncan's multiple range test was used to resolve the differences between treatment means (Steel and Torrie, 1980). Differences between treatment means were considered significant at $P<0.05$.

\section{RESULTS}

Values of growth performance parameters as initial and final body weights, total gain in weight, average daily gain (ADG mg/day/fish) and specific growth rate (SGR, $\%$ /day), are illustrated in Table (3). The results of silage type indicated that fish receiving diets containing FWSP, achieved significantly $(P<0.05)$ higher growth performance compared to those receiving diets contained SHSP. Irrespective of silage type (fish waste or shrimp head protein), as silage protein increased in the diets of fish, as the growth performance parameters decreased. However, nonsignificant $(P$ $>0.05$ ) differences were noticed among fish fed the control, the 15 and the $30 \%$ silage protein diets. Moreover, there were insignificant $(P>0.05)$ differences among fish fed diets containing 15,30 and $45 \%$ of fish meal protein in the form of silage protein, likewise between fish fed 45 and $60 \%$ silage protein in relation to growth performance parameters. As shown in Table 3, results of the interaction indicated that the replacement levels of FWSP instead of FMP had nonsignificant $(P>0.05)$ growth performance compared to the control group. Similar results were found among fish fed the control diet and those fed the 15 and $30 \%$ SHSP diet, also among fish fed diets containing 15, 30 and $45 \%$ SHSP and finally among fish fed diets containing 30,45 and $60 \%$ SHSP instead of FMP. As a rule, the replacement of FWSP up to $60 \%$, and SHSP up to $30 \%$ instead of FMP had no depressing effect on growth performance of fish compared to those fed on the control diet. Otherwise, Table 4 shows that there is a positive correlation between silage protein (FWSP and SHSP) and growth parameters (final weight, weight gain, average daily gain and specific growth rate).

Results of averages nutritional parameters including feed intake, feed conversion ration (FCR), protein efficiency ration (PER), protein productive value (PPV, \%) and energy utilization (EU, \%) are presented in Table 5. Feed intake of fish receiving diet with FWSP did not differ significantly than that with SHSP in diet. However, FCR, PER and PPV were significantly $(P<0.05)$ better in fish fed diet containing FWSP. Conversely, EU was significantly $(P<0.05)$ higher in that receiving SHSP in their diet. As for silage level, insignificant $(P>0.05)$ differences were recorded among fish fed on diets containing $0,15,30$ and $45 \%$ silage protein for feed intake and PER. Up to $30 \%$ silage protein instead of FMP, FCR did not significantly $(P>0.05)$ affected, however at 45 and $60 \%$ silage protein substitution, FCR was significantly $(P>0.05)$ depressed. On the other hand, with increasing silage protein in the diets, PPV (\%) decreased significantly, with insignificant $(P>0.05)$ deference between fish fed 45 and $60 \%$ of the FMP as silage protein in their diets. Energy utilization (\%) of fish fed diets containing 0,30 and $60 \%$ were differed significantly when compared with those fed diets containing 15 and $45 \%$ silage protein, with insignificant $(P>0.05)$ differences between the two groups. Concerning the interaction effects, Table 6 , shows that up to $60 \%$ FWSP feed intake, FCR and PER of fish did not affected significantly compared to the control group. Meanwhile, SHSP substitution levels up to $45 \%$ for feed intake and up to $30 \%$ for FCR and PER did not differ significantly $(P>0.05)$ than those fed on FWSP or control diet. On the contrary, as FWSP or 
SHSP levels increased, PPV $(\%)$ decreased with insignificant $(P>0.05)$ difference between that received $15 \%$ FWSP and the control group. The higher percentage of EU was attained by fish fed the control diet and that fed on diet containing $30 \%$ SHSP than significant $(P<0.05)$ differences with those fed on 15 and $45 \%$ FWSP as well as with those fed on 15, 45 and $60 \%$ SHSP in their diet. On the other hand, Table 6 shows that there is a positive correlation between silage protein (FWSP and SHSP) and feed utilization parameters (Feed intake, FCR, PER, PPV and EU).

Table 3. Growth performance of Nile tilapia fed different levels of fish waste silage protein (FWSP) or shrimp head silage protein (SHSP)

\begin{tabular}{|c|c|c|c|c|c|}
\hline Items & $\begin{array}{c}\text { Initial } \\
\text { weight } \\
\text { (g/fish) }\end{array}$ & $\begin{array}{c}\text { Final } \\
\text { weight } \\
\text { (g/fish) }\end{array}$ & $\begin{array}{l}\text { Gain }^{1} \\
\text { (g/fish) }\end{array}$ & $\begin{array}{c}\mathrm{ADG}^{2} \\
\text { (mg/fish/day) }\end{array}$ & $\begin{array}{l}\mathrm{SGR}^{3} \\
\% / \text { day }\end{array}$ \\
\hline & \multicolumn{5}{|c|}{ Silage type, $T$} \\
\hline FWSP & 12.4 & $101.46^{\mathrm{a}}$ & $89.06^{\mathrm{a}}$ & $0.795^{\mathrm{a}}$ & $1.870^{\mathrm{a}}$ \\
\hline \multirow[t]{2}{*}{ SHSP } & 12.4 & $90.33^{\mathrm{b}}$ & $77.93^{\mathrm{b}}$ & $0.696^{\mathrm{b}}$ & $1.766^{\mathrm{b}}$ \\
\hline & \multicolumn{5}{|c|}{ Silage level, \% (L) } \\
\hline 0 & 12.4 & $106.35^{\mathrm{a}}$ & $93.95^{\mathrm{a}}$ & $0.839^{\mathrm{a}}$ & $1.917^{\mathrm{a}}$ \\
\hline 15 & 12.4 & $102.50^{\mathrm{ab}}$ & $90.10^{\mathrm{ab}}$ & $0.804^{\mathrm{ab}}$ & $1.882^{\mathrm{ab}}$ \\
\hline 30 & 12.4 & $98.65^{\mathrm{ab}}$ & $86.25^{\mathrm{ab}}$ & $0.770^{\mathrm{ab}}$ & $1.848^{\mathrm{ab}}$ \\
\hline 45 & 12.4 & $90.60^{\mathrm{bc}}$ & $78.20^{\mathrm{bc}}$ & $0.698^{\mathrm{bc}}$ & $1.769^{\mathrm{bc}}$ \\
\hline 60 & 12.4 & $8138^{\mathrm{c}}$ & $68.98^{\mathrm{c}}$ & $0.616^{\mathrm{c}}$ & $1.676^{\mathrm{c}}$ \\
\hline Diets & \multicolumn{5}{|c|}{ Interaction $\mathbf{T} \times \mathbf{L}$} \\
\hline Control & 12.4 & $106.35^{\mathrm{a}}$ & $93.95^{\mathrm{a}}$ & $0.839^{\mathrm{a}}$ & $1.92^{\mathrm{a}}$ \\
\hline 15 FWSP & 12.4 & $106.75^{\mathrm{a}}$ & $94.35^{\mathrm{a}}$ & $0.842^{\mathrm{a}}$ & $1.92^{\mathrm{a}}$ \\
\hline 30 FWSP & 12.4 & $103.65^{\mathrm{ab}}$ & $91.25^{\mathrm{ab}}$ & $0.815^{\mathrm{ab}}$ & $1.89^{\mathrm{ab}}$ \\
\hline 45 FWSP & 12.4 & $97.3^{\mathrm{abc}}$ & $84.90^{\mathrm{abc}}$ & $0.758^{\mathrm{abc}}$ & $1.84^{\mathrm{ab}}$ \\
\hline 60 FWSP & 12.4 & $87.30^{\mathrm{abc}}$ & $74.9^{\mathrm{abc}}$ & $0.669^{\mathrm{abc}}$ & $1.74^{\mathrm{abc}}$ \\
\hline 15 SHSP & 12.4 & $98.25^{\mathrm{ab}}$ & $85.85^{\mathrm{ab}}$ & $0.767^{\mathrm{ab}}$ & $1.85^{\mathrm{ab}}$ \\
\hline 30 SHSP & 12.4 & $93.65^{\mathrm{abc}}$ & $81.25^{\mathrm{abc}}$ & $0.725^{\mathrm{abc}}$ & $1.80^{\mathrm{abc}}$ \\
\hline 45 SHSP & 12.4 & $83.90^{\mathrm{bc}}$ & $71.5^{\mathrm{bc}}$ & $0.638^{b c}$ & $1.71^{\mathrm{bc}}$ \\
\hline 60 SHSP & 12.4 & $75.45^{\mathrm{c}}$ & $63.05^{\mathrm{c}}$ & $0.563^{\mathrm{c}}$ & $1.61^{\mathrm{c}}$ \\
\hline $\begin{array}{l}\text { Means in the } \\
(P<0.05) . \\
{ }^{1} \text { Gain }(\mathrm{g} / \text { fish })= \\
{ }^{2} \text { Average daily } \\
{ }^{3} \text { Specific growtl }\end{array}$ & olumn & ach item & different & pt are signif & ly differen \\
\hline
\end{tabular}

Table 4. Linear regression of FWSP and SHSP relationships between dietary inclusion levels $(x)$ and growth performance parameters $(y)$

\begin{tabular}{lll}
\hline \multirow{2}{*}{ Parameters } & \multicolumn{2}{c}{ Equation } \\
\cline { 2 - 3 } & \multicolumn{1}{c}{ FWSP } & \multicolumn{1}{c}{ SHSP } \\
\hline Final weight & $\mathrm{y}=109.78-0.317 \mathrm{x}$ & $\mathrm{y}=106.75-0.507 \mathrm{x}$ \\
Weight gain & $\mathrm{y}=97.38-0.317 \mathrm{x}$ & $\mathrm{y}=94.35-0.507 \mathrm{x}$ \\
Average daily gain & $\mathrm{y}=0.869-0.0028 \mathrm{x}$ & $\mathrm{y}=0.843-0.0045 \mathrm{x}$ \\
Specific growth rate & $\mathrm{y}=1.948-0.0029 \mathrm{x}$ & $\mathrm{y}=1.928-0.005 \mathrm{x}$ \\
\hline
\end{tabular}


Table 5. Feed and nutrient utilization averages of Nile tilapia fed different levels of fish waste silage protein (FWSP) or shrimp head silage protein (SHSP)

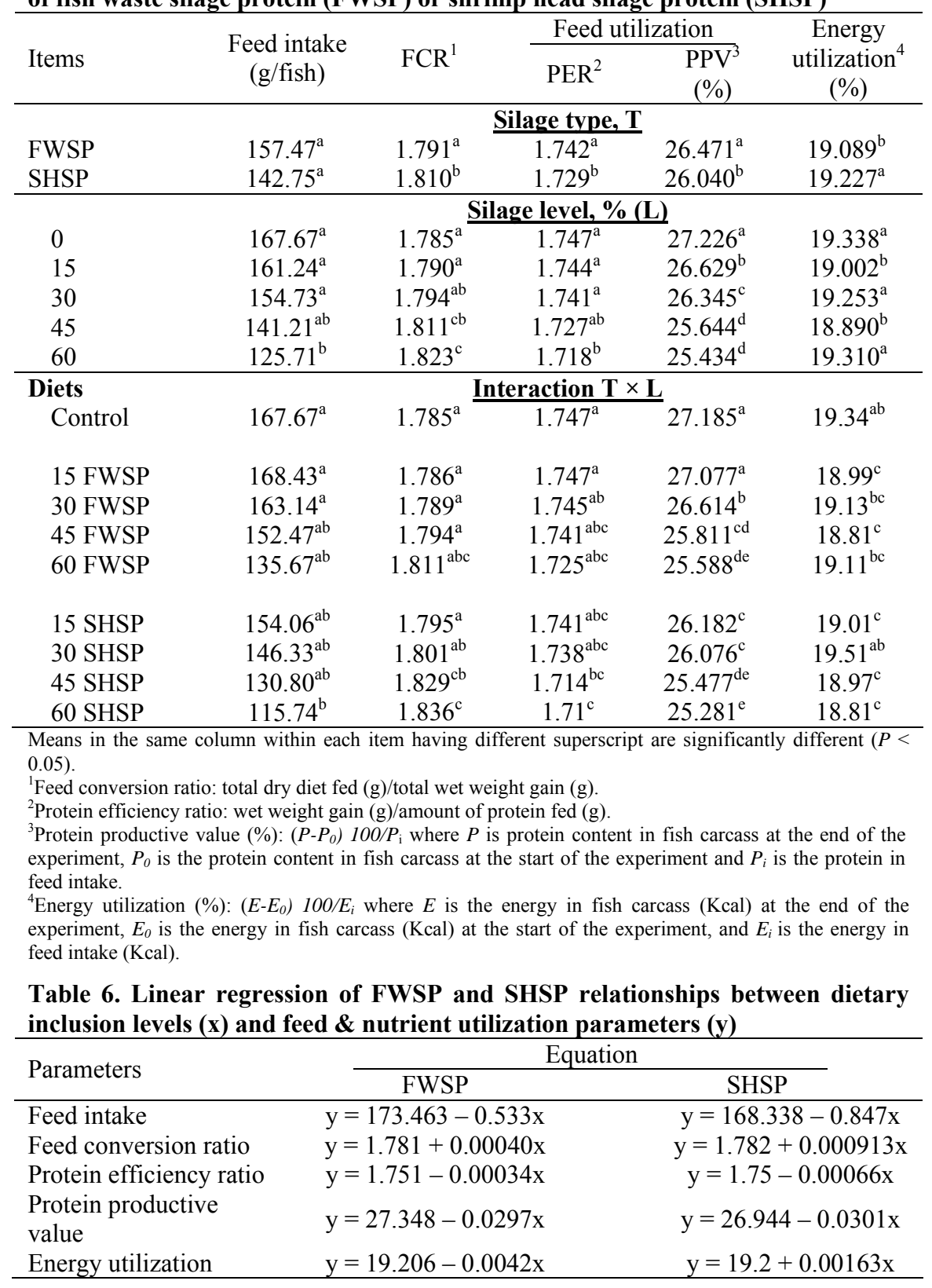


Proximate body compositions (\%) of Nile tilapia fed on diets contained FWSP or SHSP instead of FMP are shown in Table 7. There was nonsignificant $(P>0.05)$ difference between fish receiving diet containing FWSP and that received diet containing SHSP for dry matter (DM), ash, gross energy (GE kcal/100 g DM) and hepatosomatic index (HSI). Crude protein was significantly $(P<0.05)$ higher in the group of fish fed on FWSP than those fed on SHSP. Conversely ether extract (EE) was significantly $(P<0.05)$ higher in fish fed SHSP. Regarding the effect of silage protein level, dry matter contents and HSI did not differ significantly with increasing silage protein level. Fish fed diet containing 0 and $15 \%$ silage protein gained significantly $(P<0.05)$ higher crude protein compared to those fed on 45 and $60 \%$ silage protein. Otherwise, up to $45 \%$ silage protein, ash and GE contents were not affected, though, fish fed a diet containing $60 \%$ silage protein had significantly $(P<$ $0.05)$ higher GE and lower ash contents. Results of the interaction indicated that the effect DM contents were not significant at all treatments. However, crude protein of fish fed FWSP did not differ significantly with those fed the control diet, meanwhile, up to $30 \%$ SHSP did not differ significantly with fish received the control group. The control group gained the lowest percentage of EE with nonsignificant $(P>0.05)$ differences among 15, 30, $45 \%$ FWSP and $15 \%$ SHSP. Whereas, fish fed diet containing $60 \%$ of FWSP or SHSP attained higher EE content compared to other groups. Moreover, fish fed diets containing 0, 15, 30 and $45 \%$ of FWSP or SHSP had significantly $(P<0.05)$ higher carcass ash contents than other fish groups. There was a slight, but significant $(P<0.05)$ increase in GE contents of fish carcasses in all treatments where, the higher GE was attained with diet contained $60 \%$ SHSP. Notably, HSI did not show any significant differences among dietary treatments. However, Table 8 shows that there is a positive correlation between silage protein (FWSP and SHSP) and carcass composition contents (Crude protein, Ether extract, Ash and Gross energy).

Economic evaluation results of using FWSP or SHSP instead of FMP is displayed in Table 9. The results showed that the feed cost was decreased with increasing FWSP or SHSP instead of FMP. Similarly, the amount of feed $/ \mathrm{kg}$ fish gain and the cost of $\mathrm{kg}$ fish gain had the same trend of feed cost. Whereas, the changes in feed cost $/ \mathrm{kg}$ gain (\%) compared to the control diet was decreased linearly with increasing the substitution level until reaching 14 and $18 \%$ of FWSP and SHSP instead of FMP, respectively. On the other hand, diet containing SHS exceeded that contained FWS in decreasing feed cost and changing the feed cost $/ \mathrm{kg}$ gain (\%) compared to control. However, the trend indicated possibility disparity in the costs of using diet without FWSP or SHSP; and more profits was obtained by using diets that contain FWSP or SHSP. 
Table 7. Proximate body composition and hepatosomatic index averages of Nile tilapia fed different levels of fish waste silage protein (FWSP) or shrimp head silage protein (SHSP)

\begin{tabular}{|c|c|c|c|c|c|c|}
\hline \multirow[b]{2}{*}{ Items } & \multirow{2}{*}{$\begin{array}{l}\text { Dry } \\
\text { matter } \\
(\%)\end{array}$} & \multicolumn{3}{|c|}{ On dry matter basis $(\%)$} & \multirow[b]{2}{*}{$\begin{array}{l}\text { Gross } \\
\text { energy } 1\end{array}$} & \multirow[b]{2}{*}{$\mathrm{HSI}^{2}$} \\
\hline & & $\begin{array}{l}\text { Crude } \\
\text { protein }\end{array}$ & Ether extract & Ash & & \\
\hline & \multicolumn{6}{|c|}{ Silage type, $T$} \\
\hline FWSP & $27.86^{\mathrm{a}}$ & $54.26^{\mathrm{a}}$ & $22.72^{\mathrm{b}}$ & $23.02^{\mathrm{a}}$ & $521.45^{\mathrm{a}}$ & $5.75^{\mathrm{a}}$ \\
\hline \multirow[t]{2}{*}{ SHSP } & $27.97^{\mathrm{a}}$ & $53.32^{\mathrm{b}}$ & $23.90^{\mathrm{a}}$ & $22.78^{\mathrm{a}}$ & $525.77^{\mathrm{a}}$ & $6.10^{\mathrm{a}}$ \\
\hline & \multicolumn{6}{|c|}{ Silage level, \% (L) } \\
\hline 0 & $28.38^{\mathrm{a}}$ & $54.40^{\mathrm{a}}$ & $22.20^{\mathrm{d}}$ & $23.40^{\mathrm{a}}$ & $516.39^{\mathrm{b}}$ & $5.70^{\mathrm{a}}$ \\
\hline 15 & $27.85^{\mathrm{a}}$ & $54.33^{\mathrm{a}}$ & $22.32^{\mathrm{cd}}$ & $23.35^{\mathrm{a}}$ & $518.32^{\mathrm{b}}$ & $5.71^{\mathrm{a}}$ \\
\hline 30 & $27.95^{\mathrm{a}}$ & $53.60^{\mathrm{ab}}$ & $23.30^{\mathrm{bc}}$ & $23.10^{\mathrm{a}}$ & $523.07^{\mathrm{b}}$ & $5.58^{\mathrm{a}}$ \\
\hline 45 & $27.75^{\mathrm{a}}$ & $53.35^{\mathrm{b}}$ & $23.75^{\mathrm{b}}$ & $22.90^{\mathrm{a}}$ & $523.77^{\mathrm{b}}$ & $6.26^{\mathrm{a}}$ \\
\hline 60 & $27.65^{\mathrm{a}}$ & $53.20^{\mathrm{b}}$ & $25.05^{\mathrm{a}}$ & $21.75^{\mathrm{b}}$ & $536.52^{\mathrm{a}}$ & $6.37^{\mathrm{a}}$ \\
\hline Diets & \multicolumn{6}{|c|}{ Interaction $\mathbf{T} \times \mathbf{L}$} \\
\hline Control & $28.30^{\mathrm{a}}$ & $54.40^{\mathrm{ab}}$ & $22.20^{\mathrm{c}}$ & $23.40^{\mathrm{a}}$ & $516.38^{b}$ & $5.69^{\mathrm{a}}$ \\
\hline 15 FWSP & $28.00^{\mathrm{a}}$ & $54.80^{\mathrm{a}}$ & $21.80^{\mathrm{c}}$ & $23.40^{\mathrm{a}}$ & $514.86^{\mathrm{b}}$ & $5.46^{\mathrm{a}}$ \\
\hline 30 FWSP & $27.90^{\mathrm{a}}$ & $54.20^{\mathrm{ab}}$ & $22.80^{\mathrm{bc}}$ & $23.00^{\mathrm{ab}}$ & $520.92^{\mathrm{ab}}$ & $5.32^{\mathrm{a}}$ \\
\hline 45 FWSP & $27.6^{0 \mathrm{a}}$ & $53.80^{\mathrm{ab}}$ & $23.20^{\mathrm{bc}}$ & $23.00^{\mathrm{ab}}$ & $522.44^{\mathrm{ab}}$ & $5.97^{\mathrm{a}}$ \\
\hline 60 FWSP & $27.50^{\mathrm{a}}$ & $53.60^{\mathrm{ab}}$ & $24.40^{\mathrm{ab}}$ & $22.00^{b c}$ & $532.64^{\mathrm{ab}}$ & $6.30^{\mathrm{a}}$ \\
\hline 15 SHSP & $27.70^{\mathrm{a}}$ & $53.85^{\mathrm{ab}}$ & $23.10^{\mathrm{bc}}$ & $23.05^{\mathrm{ab}}$ & $521.78^{\mathrm{ab}}$ & $5.97^{\mathrm{a}}$ \\
\hline 30 SHSP & $28.00^{\mathrm{a}}$ & $53.20^{\mathrm{ab}}$ & $24.00^{\mathrm{b}}$ & $22.80^{\mathrm{abc}}$ & $526.61^{\mathrm{ab}}$ & $5.85^{\mathrm{a}}$ \\
\hline 45 SHSP & $27.90^{\mathrm{a}}$ & $52.85^{\mathrm{b}}$ & $23.90^{\mathrm{b}}$ & $23.25^{\mathrm{ab}}$ & $523.69^{\mathrm{ab}}$ & $6.55^{\mathrm{a}}$ \\
\hline 60 SHSP & $27.80^{\mathrm{a}}$ & $52.80^{\mathrm{b}}$ & $25.70^{\mathrm{a}}$ & $21.50^{\mathrm{c}}$ & $540.40^{\mathrm{a}}$ & $6.45^{\mathrm{a}}$ \\
\hline \multicolumn{7}{|c|}{$\begin{array}{l}\text { Means in the same column within each item having different superscript are significantly different } \\
(P<0.05) \text {. } \\
\text { 'Gross energy (Kcal/100 g dry matter), calculated on the basis of } 5.64,4.11 \text { and } 9.44 \mathrm{Kcal} \mathrm{GE} / \mathrm{g} \text { protein, } \\
\text { NFE and lipid, respectively (NRC, 1993). } \\
\text { ' }\end{array}$} \\
\hline
\end{tabular}

Table 8. Linear regression of FWSP and SHSP relationships between dietary inclusion levels $(x)$ and carcass composition parameters $(y)$

\begin{tabular}{lcc}
\hline \multirow{2}{*}{ Parameters } & \multicolumn{2}{c}{ Equation } \\
\cline { 2 - 3 } & $\mathrm{y}=54.68-0.0173 \mathrm{x}$ & $\mathrm{y}=54.26-0.028 \mathrm{x}$ \\
Crude protein & $\mathrm{y}=21.72+0.0387 \mathrm{x}$ & $\mathrm{y}=22.22+0.052 \mathrm{x}$ \\
Ether extract & $\mathrm{y}=23.72-0.023 \mathrm{x}$ & $\mathrm{y}=23.50-0.024 \mathrm{x}$ \\
Ash & $\mathrm{y}=513.432+0.277 \mathrm{x}$ & $\mathrm{y}=515.783+0.333 \mathrm{x}$ \\
\hline
\end{tabular}


Table 9. Averages of costs evaluation (Dollar) for production of one $\mathrm{kg}$ Nile tilapia fed different levels of FWSP or SHSP instead of FMP

\begin{tabular}{ccccc}
\hline Diets & $\begin{array}{c}\text { Feed cost } \\
\text { (Dollar/ton } \\
\text { feed) }\end{array}$ & $\begin{array}{c}\text { Amount of } \\
\text { feed/kg gain }\end{array}$ & $\begin{array}{c}\text { Feed cost of kg } \\
\text { fish gain } \\
\text { (Dollar) }\end{array}$ & $\begin{array}{c}\text { Reduction in feed } \\
\text { cost/kg gain }(\%) \\
\text { compared to control }\end{array}$ \\
\hline $1^{*}$ & 752.6 & 1.79 & 1.347 & $*$ \\
2 & 721.3 & 1.79 & 1.291 & 4.159 \\
3 & 714.2 & 1.79 & 1.278 & 5.102 \\
4 & 690.0 & 1.79 & 1.235 & 8.318 \\
5 & 675.9 & 1.81 & 1.223 & 9.188 \\
6 & 658.7 & 1.80 & 1.187 & 11.988 \\
7 & 637.5 & 1.80 & 1.148 & 14.820 \\
8 & 627.5 & 1.83 & 1.148 & 14.759 \\
9 & 599.1 & 1.84 & 1.102 & 18.172 \\
\hline
\end{tabular}

* Used as a base for calculation

Diets $1,2,3,4$ and 5 contained $0,15,30,45$ and $60 \%$ FWSP, respectively.

Diets $6,7,8$ and 9 contained $15,30,45$ and $60 \%$ SHSP, respectively.

The cost of the diet ingredients (on dry matter basis) were put at: 7500, 2500, 1500, 3500, 1800, 1000, 1900, 7000 and $16000 \mathrm{LE} /$ ton for Fish meal, FWS, SHS, Soybean meal, Yellow corn, Rice particles, Wheat bran, Vegetable oil and Min. \& Vit., respectively. All of ingredients price divided on 5.5 (Dollar to LE exchange price), Price of 2007 year.

\section{DISCUSSION}

The use of fish and shrimp head silage in the feeding of fish has been widely studied. Due to the similarity of this protein source with the raw material and low cost, especially when compared to fish meal, silage has a high potential use in aquaculture. (Hussain and Offer, 1987; Fagbenro et al., 1994; Vidotti et al., 2003; Goddard and Perret, 2005). The present study is an attempt to evaluate the potential use of fish waste and shrimp head silage protein instead of FMP in practical diets for Nile tilapia. The obtained results exhibited that growth performance, feed and nutrients utilization of fish fed diets containing FWSP surpassed those fed diets containing SHSP. This may be due to the relatively higher contents of ash (Bhuiyan, 1989), crude fiber (Oku et al., 1982; Ward and Reichert, 1986; Cavalheiro et al., 2007)) and NFE in SHS comparing with those in FWS (Table 1). Accordingly, the apparent digestibility coefficient of FWS was higher than that of SHS (Borghesi, 2004). High levels of non-protein nitrogen ( $45 \%$ in shrimp head silage) free amino acids, peptides resulting from proteolysis interfere with protein absorption. Such loss of dietary protein is detrimental to efficient protein utilization (Batista et al., 1989 and Fagbenro et al., 1994) and the lower growth performance, feed and nutrient utilization which attributed to the adsorption of enzymes and proteins by carbohydrates in the diet (Fagbenro and Bello-Olusoji, 1997). The differences between FWS and SHS utilization may due to variations in amino acids contents and essential enzymatic activity to utilize each of them. Shrimp head silage protein was deficient in tryptophan, which was not determined, because it is known that it is labile under acid conditions (Hansen and Illanes, 1994). On the other hand, fermented fish silage in diets fed to tilapia had positive effects on feed utilization and digestibility (Fagbenro, 1994; and Fagbenro and Bello-Olusoji, 1997). Similar trends 
were observed in the present work with FWSP added to tilapia diets. PlascenciaJatomea et al. (2002) deemed that one of the most difficulties observed when using alternative sources of animal proteins is the acceptance of the food, evidently related to its palatability. In the present study feed intake of fish fed on either silage type was insignificant. Chitin and chitosan have been reported to have an adverse effect on body weight and feed conversion ratio in O. niloticus and O. aureus, (Bhuiyan, 1989; Shiau and YU, 1999). So the retardation in growth performance and feed utilization may due to the chitin and chitosan contained in SHSP compared to FWSP which almost free from chitin and chitosan.

Results of the present study indicated that up to $30 \%$ silage, growth performance and feed utilization within treatments were similar to the control group. PlascenciaJatomea et al. (2002) and Refstie et al. (2004) found that shrimp head silage protein is of adequate nutritional value for tilapia fry at low levels (up to $15 \%$ ), making possible substitution levels of up to $20 \%$ of dietary animal protein without adverse effects on growth and feeding efficiency. Moreover, the better performance of fish fed the silage of FM diets might be the presence of pre-hydrolysed protein, which facilitates digestion and therefore assimilation. Fagbenro (1994) reported similar behavior for tilapia fed dried fermented fish silage. It is known that fish can assimilate protein as amino acids and short peptides, so the protein breakdown during the treatment could have a positive effect on the digestibility and assimilation of this nutrient (Plascencia-Jatomea et al., 2002). On the other hand, the reduction in growth performance and fed utilization in the higher levels of dietary silage (45 and $60 \%$ ) may partly due to thiaminase, which is possibly, present in the silage and will cause vitamin $B_{1}$ deficiency (Hidayat and Rustami, 1979). In this respect, Fagbenro and Jauncey (1994) found that fermented fish-silage co-dried with protein feedstuffs is a suitable protein supplement, which can provide up to $50 \%$ of dietary protein without affecting feed efficiency, fish growth or health. Different works on warm water species including the Indian carp, Cirrhinus mrigala (Ali et al., 1994) tilapia, $O$. niloticus. (Fagenbro and Jauncey, 1993) O. aureus (Goddard and Al-Yahyai, 2001; Goddard et al., 2003) and pacu, Piriactus mesapotamicus (Vidotti et al., 2002), have shown that fish silage is highly digestible and effective replacement for up to $75 \%$ of fish meal in aquafeeds. Liang et al. (2006) reported that the dietary addition of $15 \%$ fish protein hyrolysed (FPH) prepared from pollock by-products supported higher growth in Japanese sea bass compared with higher and lower inclusion levels. Additionally, the use of shrimp head silage in African Catfish, Clarias gariepinus, as a replacement for fish meal at $0-100 \%$ levels did not showed any statistical difference among treatment including the control in commercial feed, in terms of gain in length, weight, and growth factor (Cavalheiro et al., 2007).

Slightly significant differences were observed in carcass composition where fish fed on diets containing FWSP had significantly $(P<0.05)$ higher crude protein and lower EE. Similarly, slightly skewing upward (EE and GE) and downward (crude protein and ash) with increasing silage levels apart from its type. The DM contents and HSI did not differ significantly within silage types, levels or interaction. Therefore, the obtained results are in partial agreement with the findings of Fagbenro et al. (1994) and Cavalheiro et al. (2007) and in agreement with observations made by (Nwanna, 2003) on African Catfish. 
The economic evaluation of the present study revealed that the feed cost and the change in feed cost/kg fish gain were decreased linearly with increasing the substitution of FWSP and SHSP instead of FMP. Some authors, trying to evaluate the use of fish silage in salmon (Salmo salar) feeding, concluded that although this silage did not promote a better development, it did not cause a significant decrease and its cost was much lower (Espe et al., 1992; Heras et al., 1994). However, the obtained results are in accordance with the explanation of (Nwanna, 2003) on the economical evaluation of substation of fermented shrimp head waste meal at the expense of FM in African catfish diets.

\section{CONCLUSION}

The results of this study show that FWSP and SHSP could substitute fish meal protein in Nile tilapia feed up to 60 and $30 \%$, respectively without affecting its growth and, at the same time, being more economical.

\section{REFFERENCES}

Ali, M.Z., G.S. Zaher, M.A. Hossain and M.N. Islam, 1994. Evaluation of fish silage from underutilized marine fishes as protein sources in the diet of major carp (Cirrhinus mrigala). J. Aqua. Trop., 8: 247-254.

AOAC, 1999. Official Methods of Analysis of Association of Official Analytical Chemists, $16^{\text {th }}$ ed., AOAC International, Washington, DC., USA.

Balogun, A.M., and Y. Akegbejo-Samsons, 1992. Waste yield, proximate and mineral composition of shrimp resources of Nigeria's coastal waters. Biores. Technol., 40: 157- I61.

Batista, I., M.L. Nunes, R. Mendes and M.C. Nunes, 1989. Preparation, characterization and quality control of different kinds of fish silage. NATO Project (Technology of Fish Feed Production) Technical Report, INIP, Lisbon, 21.

Beerli, E.L., K.M. Beerli and P.V. Logato, 2004. Silagem acida de resíduos de truta (Oncorhyncus mykiss) com a utilização de ácido muriático. Ciência Agrotec., 28: $195-198$.

Bhuiyan, A.K., 1989. Survey of Potential Fish Feed Ingredients of Bangladesh on the Basis of their Availability and Biochemical Composition. Fisheries Research Institute, Freshwater Station, Mymensingh, Bangladesh, Report No. 1, 70 pp.

Borghesi, R., 2004. Avaliação físico-química e biológica das silagens ácida, biológica $\mathrm{E}$ enzimática elaboradas com descarte e resíduo do beneficiamento da tilápia do nilo (Oreochromis niloticus). Dissertação (Mestrado) - Escola Superior de Agric. "Luiz de Queiroz".

Cavalheiro, J.M., E.S. Oliveira and P.S. Bora, 2007. Utilization of shrimp industry waste in the formulation of tilapia (Oreochromis niloticus Linnaeus) feed. Bioresource Technol., 98: $602-606$. 
Espe, M., H. Haaland and L.R. Njaa, 1992. Autolysed fish silage a feed ingredient for Atlantic Salmon (Salmo salar). Composition Biochemistry Physiol., 103: 369 -372 .

Espe, M., J. Raa and L.R. Njaa, 1989. Nutritional value of stored fish silage as a protein source for young rats. J. Sci. Food Agric., 49: $259-270$.

Fagbenro, O.A., 1994. Dried fermented fish silage in diets of Oreochromis niloticus. Isr. J. Aquacult-Bamid 46: 140 - 147.

Fagbenro, O.A. and O.A. Bello-Olusoji, 1997. Preparation, nutrient composition and digestibility of fermented shrimp head silage. Food Chem., 60: $489-493$.

Fagbenro, O.A., K. Jauncey and G. Haylor, 1994. Nutritive value of diets containing dried lactic acid fermented fish silage and soybean meal for juvenile Oreochromis niloticus and Clarias gariepinus. Aquat. Liv. Resour., 7: 79 - 85 .

Fagbenro, O. and K. Jauncey, 1994. Growth and protein utilization by juvenile catfish (Clarias gariepinus) fed dry diets containing co-dried lactic-acidfermented fish silage and protein feed stuffs. Bioresource Technol., 51: $29-$ 35 .

Fagenbro, O. and K. Jauncey, 1993. Chemical and nutritional quality of raw, cooked and salted silages. Food Chem., 48: 331- 335.

Ferraz de Arruda, L., 2004. Aproveitamento do resíduo do beneficiamento da tilápia do nilo (Oreochromis niloticus) para obtenção de silagem e óleo como subprodutos. Dissertação (Mestrado) - Escola Superior De Agric. "Luiz De Queiroz”, Universidade De São Paulo, Piracicaba, Brasil., 78 p.

Foltz, J.W., J.M. Gibson and J.T. Windell, 1982. Evaluation of tilapia meal for fish diets. Progressive Fish-Culturist, 44: $8-11$.

Gao, Y., K.V. Lo, and P.H. Liao, 1992. Utilization of salmon farm mortalities-fish silage. Bioresource Technol., 41: 123 - 127.

Giri, S.S., S.K. Sahoo, A.K. Sahu and P.K. Mukhopadhyay, 2000. Nutrient digestibility and intestine enzyme activity of Clarias batrachus (Linn) juveniles fed on dried fish and chicken viscera incorporated diets. Biores. Technol., 71: 97 - 101 .

Goddard, J.S. and D.S. Al-Yahyai, 2001. Chemical and nutritional characteristics of dried sardine silage. J. Aquat. Food Product Technol., 10: 39 - 50.

Goddard, J.S., E. McLean and K. Wille, 2003. Co-dried sardine silage as an ingredient in tilapia, Oreochromis aureus, diets. J. Aquat. Trop., 18: 257-264.

Goddard, J.S. and J.S. Perret, 2005. Co-drying fish silage for use in aquafeeds. Anim. Feed Sci. Technol., 118: $337-342$.

Haard, N.F., 1992. Control of chemical composition and food quality attributes of cutured fish. Food Res. Internat., 25: 289 - 307.

Hansen, M.E. and A. Illanes, 1994. Applications of crustacean wastes in biotechnology, in fisher processing: Biotechnological Applications, Ed by Martin A. M. Chaman and Hall, London, PP $174-205$.

Hepher, B., 1988. Nutrition of pond fishes. ISBN $1^{\text {st }}$ ed., The Press Syndicate of the University of Cambridge, UK.

Heras, H., C.A. McLeod and R.G. Ackman, 1994. Atlantic dogfish silage vs. herring silage in diets for Atlantic salmon (Salmo salar): growth and sensory evaluation of fillets. Aquacult., 125: 93 - 106. 
Hidayat, D. and D. Rustami, 1979. Fish silage as a feed for fresh water fish. Indopacific fisheries commission workshop on fish silage production and its use, FAO, Djakarta, $17-21$ September.

Hu, M., Y. Wang, Q. Wang, M. Zhao, B. Xiong, X. Qian, Y. Zhao and Z. Luo, 2008. Replacement of fish meal by rendered animal protein ingredients with lysine and methionine supplementation to practical diets for gibel carp, Carassius auratus gibelio. Aquacult., 275: $260-265$

Hussain, R.A. and N.W. Offer, 1987. Effect of folmaldehyde treatment on the degradation of acid preserved fish silage protein in vitro. Anim. Feed Sci. Technol., 16: 297 - 304.

Kompiang, I. P., 1981. Fish silage: its prospect and future in Indonesia. Indonesia Agric. Res. and Dev. J., 3, 9 - 12.

Liang, M., J. Wang, Q. Chang and K. Mai, 2006. Effects of different levels of fish protein hydrolysate in the diet on the nonspecific immunity of Japanese sea bass, Lateolabrax japonicus (Cuvieret Valenciennes, 1928). Aquacult. Res., 37: $102-106$.

Lo, K.V., P.H. Liao, C. Bullock and Y. Jones, 1993. Silage production from salmon farm mortalities. Aquacult. Engin., 12: $37-45$.

Meyers, S.P., 1986. Utilization of shrimp processing wastes. In/fish Marketing Digest., 4186: $18-19$.

Mohammed, F., 1977. Nutritional evaluation of poultry feeds incorporating certain agro-industrial waste products as a source of protein, Ph.D. Thesis, University of Mysore, Mysore, India.

NRC, 1993. Nutrient Requirements of Warmwater Fishes and Shellfishes, National Research Council, rev. ed., National Academy Press, Washington, DC, USA

Nwanna, L.C., 2003. Nutritional Value and Digestibility of Fermented Shrimp Head Waste Meal by African Catfish, Clarias gariepinus. Pakistan J. of Nutr., 2: $339-345$.

Ockerman, H.W., 1992. Fishery by-products. In Fish Process. Technol., ed. G. M. Hall. Blackie Academic, London, pp. 155 - 92.

Oku, T., F. Kunishi and N. Hosoy, 1982. Mechanism of inhibitory effect of unavailable carbohydrate on intestinal calcium absorption. J. Nutr., 112: 410 415.

Paul, B.N., S. Nandi, S. Sarkar and P.K. Mukhopahdyay, 1997. Effects of feeding unconventional animal protein sources on the nitrogen metabolism in rohu, Labeo rohita (Hamilton). Israeli J Aquacult., Bamidgeh, 49: 183 -192.

Plascencia-Jatomea, M., M.A. Olvera-Novoa, J.L. Arredondo-Figueroa, G.M. Hall and K. Shirai1, 2002. Feasibility of fishmeal replacement by shrimp head silage protein hydrolysate in Nile tilapia (Oreochromis niloticus L) diets. J. Sci. Food Agric., 82: 753 - 759.

Refstie, S., J.J. Olli and H. Standal, 2004. Feed intake, growth, and protein utilisation bypost-smolt Atlantic salmon (Salmon salar) in response to graded levels of fish protein hydrolysate in the diet. Aquacult., 239: 331- 349.

SAS, 1988. SAS/STAT User's Guide, Release 6.03 Edition, SAS Institute Inc., Cary, $\mathrm{NC}, 1028 \mathrm{pp}$. 
Shiau, S.Y. and Y.P. Yu, 1999. Dietary supplementation of chitin and chitosan depressed growth in tilapia, Oreochromis niloticus $\times$ O. aureus. Aquacult., 179: $439-446$.

Srour, T.M., 2005. Utilization of some unconventional protein sources in the diet of blue tilapia (O. aureus) cultured in net enclosures. J. Agric. Sci. Mansoura Univ., 12: $7521-7533$.

Steel, R.H. and J.H. Torrie, 1980. Principles and procedures of statistics: A Biometrical Approach. McGraw-Hill, New York, USA.

Tacon, A.G.J., 1993. Feed ingredients for warmwater fish: fish meal and other processed feedstuffs. FAO Fisheries Circular No. 856. FAO, Rome.

Vidotti, R.M., J.C. Dalton and E.M. Viegas, 2002. Acid and fermented silage characterization and determination of apparent digestibility coefficient of crude protein for pacu, Piriactus mesapotamicus. J. World Aqua. Soc., 33: 57 -62 .

Vidotti, R.M., E.M. Viegas and D.J. Carneiro, 2003. Amino acid composition of processed fish silage using diferent raw materials. Anim. Feed Sci. Technol., 105: $199-204$.

Ward, A.T. and R.D. Reichert, 1986. Comparison of the effect of cell wall and hull fiber from canola and soybean on the bioavailability for rats of minerals, protein and lipid. J. Nutr., 116: $233-241$. 


\section{سيلاج مخلفات الأسماك ورؤوس الجمبرى كمصادر بروتين لأسماك البلطى النيلى طارق محمد أحمد سرور \\ قسم الإنتاج الحيوانس والسمكى. كلية النزراعة، سابا باشا، جامعة الإسكندرية}

أجريت تجربة تغذية لأسماك البلطى النيلى فى سياجات شبكية من النايلون لتقدير أثر إحلال بروتين

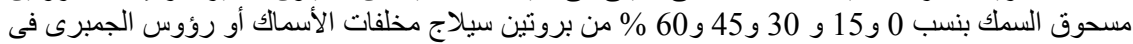

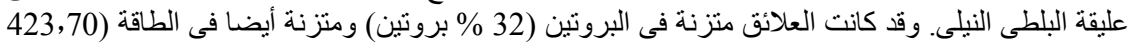

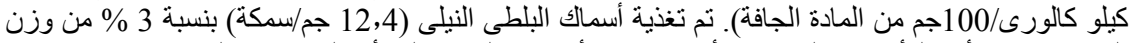

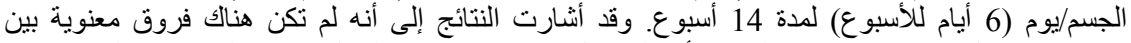

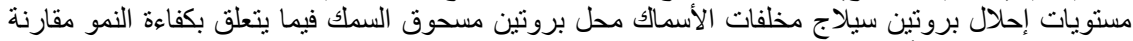

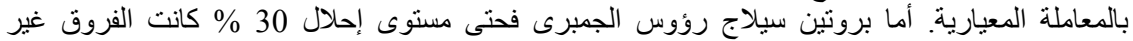

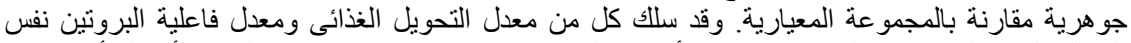

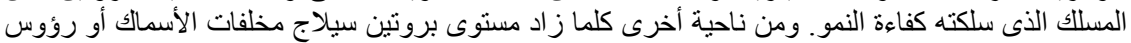

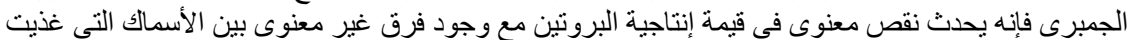

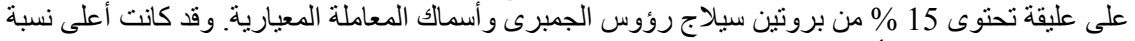

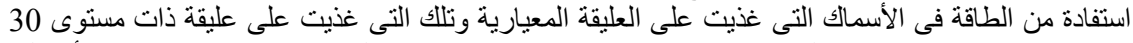

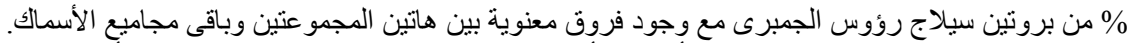

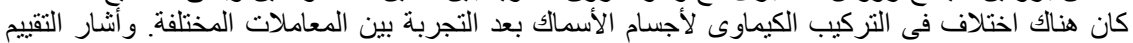

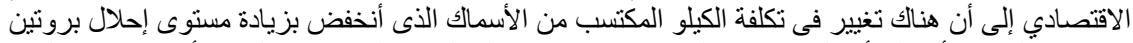

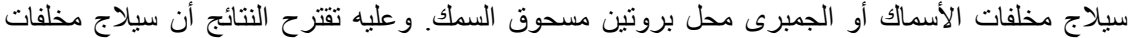

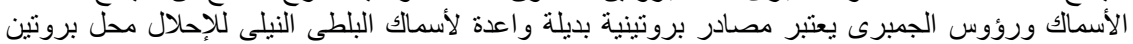

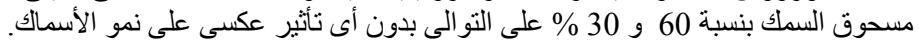

